\title{
Characterization of Nodularia strains, cyanobacteria from brackish waters, by genotypic and phenotypic methods
}

\author{
Jaana Lehtimäki, ${ }^{1}$ Christina Lyra, ${ }^{1}$ Sini Suomalainen, ${ }^{2}$ Päivi Sundman, ${ }^{2}$ \\ Leo Rouhiainen, ${ }^{1}$ Lars Paulin, ${ }^{2}$ Mirja Salkinoja-Salonen ${ }^{1}$ \\ and Kaarina Sivonen ${ }^{1}$
}

Department of Applied Chemistry and Microbiology ${ }^{1}$ and Institute of

Biotechnology2, PO Box 56 Biocentre Viikki, 00014 Helsinki University, Helsinki, Finland
Author for correspondence: Kaarina Sivonen. Tel: +358 0 19159270. Fax: +358 019159322. e-mail: kaarina.sivonen@helsinki.fi

\begin{abstract}
An investigation was undertaken of the genetic diversity of Nodularia strains from the Baltic Sea and from Australian waters, together with the proposed type strain of Nodularia spumigena. The Nodularia strains were characterized by using a polyphasic approach, including RFLP of PCR-amplified 16S rRNA genes, 165 rRNA gene sequencing, Southern blotting of total DNA, repetitive extragenic palindromic- and enterobacterial repetitive intergenic consensusPCR, ribotyping and phenotypic tests. With genotypic methods, the Nodularia strains were grouped into two clusters. The genetic groupings were supported by one phenotypic property: the ability to produce nodularin. In contrast, the cell sizes of the strains were not different in the two genetic clusters. 16S rRNA gene sequences indicated that all the Nodularia strains were closely related, despite their different origins. According to this study, two genotypes of Nodularia exist in the Baltic Sea. On the basis of the taxonomic definitions of Komárek et al. (Algol Stud 68, 1-25, 1993), the non-toxic type without gas vesicles fits the description of Nodularia sphaerocarpa, whereas the toxic type with gas vesicles resembles the species $\boldsymbol{N}$. spumigena and Nodularia baltica.
\end{abstract}

Keywords: Nodularia cyanobacterium, RFLP, 16S rDNA sequencing, REP- and ERIC-PCR, ribotyping

\section{INTRODUCTION}

The cyanobacterial genus Nodularia commonly form blooms in brackish waters such as the Baltic Sea in Europe (Sivonen et al., 1989a; Kononen et al., 1993) and in coastal lagoons and brackish water lakes in Australia (Baker \& Humpage, 1994; Jones et al., 1994). These blooms have caused numerous cases of animal poisoning (Francis, 1878; Nehring, 1993) due to a hepatotoxin called nodularin (Rinehart et al., 1988). It is a small, cyclic pentapeptide and has an $\mathrm{LD}_{50}$ of $50-70 \mu \mathrm{g} \mathrm{kg}$ when administered intra-

\footnotetext{
Abbreviations: ERIC, enterobacterial repetitive intergenic consensus; IGS, intergenic spacer; REP, repetitive extragenic palindromic; STRR, short, tandemly repeated sequence; UPGMA, unweighted pairs group method with averages.

The GenBank accession numbers for the Nodularia 16S rRNA gene sequences obtained in this study are AJ133155, AJ133158, AJ133171 and AJ133177-AJ133184.
}

peritoneally in mouse (Rinehart et al., 1988; Sivonen et al., 1989a). The toxicity of nodularin results from its ability to inhibit the serine/threonine-specific protein phosphatases PP1 and PP2A (Ohta et al., 1994). Therefore, nodularin is a potent tumour promoter and a possible carcinogen (Ohta et al., 1994). Nodularin is produced continuously by some Nodularia strains (Lehtimäki et al., 1994, 1997).

Cyanobacteria have traditionally been classified on the basis of morphology. The analysis of 16S rRNA genes has revealed that morphological characters do not necessarily result in a phylogenetically reliable taxonomy (Giovannoni et al., 1988; Wilmotte, 1994). On the basis of morphological criteria, Walsby et al. (1995), Albertano et al. (1996), Hayes \& Barker (1997) and Barker et al. (1999) found four different morphological types of Nodularia together in the Baltic Sea. One of them was not identified to the species level, whereas three were distinguished according to the criteria of Komárek et al. (1993) as Nodularia litorea, 
Nodularia spumigena and Nodularia baltica. These planktonic species, as well as the benthic species Nodularia harveyana have also been recorded from the Baltic Sea by Komárek et al. (1993). The species were differentiated by ecology and morphology such as the presence of gas vesicles, the dimensions and shapes of vegetative cells, heterocytes and akinetes and the size and shape of trichomes (Komárek et al., 1993). The properties of gas vesicles have also been used for taxonomic characterization of Nodularia, e.g. speciestypical differences in the accumulation of gas vesicles have been recorded (Komárek et al., 1993; Smarda \& Šmajs, 1996).

On the basis of the intergenic spacer region (IGS) of the phycocyanin coding sequence (PC-IGS), the genetic diversity of Nodularia populations in the southern Baltic Sea in 1996 was shown to be restricted to two distinct genotypes (Hayes \& Barker, 1997). Later, the same authors assigned Baltic Nodularia isolates to three groups based on the PC-IGS, two groups based on the gvpA-IGS and three groups based on rDNA intergenic transcribed spacer (ITS) sequences (Barker et al., 1999).

In this study, Nodularia isolates from the Baltic Sea and from Australian waters and reference strains were characterized by $16 \mathrm{~S}$ rRNA gene analysis and by totalgenome-based techniques. In addition, the ability to produce nodularin and the morphology of Nodularia strains were analysed.

\section{METHODS}

Cyanobacterial strains. The Nodularia strains were grown on Z8 medium with salt added and no nitrogen, as described in Lehtimäki et al. (1994). Other strains were grown on Z8 medium (Kotai, 1972) with or without nitrogen depending the nitrogen-fixation capability of the strains studied. The Nodularia strains were isolated from different geographical regions (Table 1). Most of them originated from the different parts of the Baltic Sea: the Arkona Sea (BY1, P38, GRD113), the Baltic proper (HKVV, F81, TEILI, 59/22, $55 / 15$ ), the Gulf of Finland (AV1, AV3, AV33, HEM, GR8a, GR8b, TR183, UP16a, UP16f) and the Gulf of Bothnia (SR5b). The locations of isolation in the Baltic Sea for strains GR8, TR183 and UP16, which are not specified in the references, are respectively $59^{\circ} 26^{\prime} 82^{\prime \prime} \mathrm{N}, 22^{\circ} 54^{\prime} 38^{\prime \prime} \mathrm{E}$; $59^{\circ} 12^{\prime} 85^{\prime \prime} \mathrm{N}, 22^{\circ} 02^{\prime} 51^{\prime \prime} \mathrm{E}$; and $59^{\circ} 41^{\prime} 87^{\prime \prime} \mathrm{N}, 23^{\circ} 28^{\prime} 22^{\prime \prime}$ E.

Information about the strains other than Nodularia used in this study is available from Rippka \& Herdman (1992) (Pasteur Culture Collection strains, designated PCC), Skulberg (1990) (Anabaena sp. strain CYA83/1) and Lehtimäki et al. (1997) (Aphanizomenon sp. strain TR183). The amounts of nodularin produced by Nodularia strains were determined by HPLC (Lehtimäki et al., 1994) and/or by ELISA with the EnviroGard Microcystins PlateKit (Strategic Diagnostics) according to the manufacturer's instructions. Axenity was tested on TGY (tryptone/ glucose/yeast extract) agar plates (Atlas, 1993) and by microscopy after Gram staining.
Morphology. The dimensions and the range of variation of vegetative cells $(n=50)$ and intercalary heterocytes $(n=50)$ were measured from axenic strains of Nodularia by light microscopy. The sizes of the akinetes were not measured, because they were not found in all strains and because incubations at high and low temperature, under low phosphorus or high salinity conditions did not induce them. Axenic cultures of 10-12 days of age were photographed.

Isolation and purification of DNA. Genomic DNA was isolated from the cultures by a procedure modified from Golden et al. (1988). Sucrose (20\% w/v), lysozyme (10 mg $\left.\mathrm{ml}^{-1}\right)$, sodium sarcosyl $(1 \% \mathrm{w} / \mathrm{v})$ and proteinase $\mathrm{K}(200 \mu \mathrm{g}$ $\mathrm{ml}^{-1}$ ) were used to lyse the cells. The Nucleon PhytoPure system (Amersham Life Science) was used to eliminate polysaccharides.

Southern blotting. For short, tandemly repeated sequences (STRR), a heptamer repeat oligonucleotide probe of Nostoc sp. PCC 7120 (5'-GGGGACTGGGGACTGGGGACTGGG-3', Bauer et al., 1993) was used to study non-axenic Nodularia strains (Table 1). DNA was digested with HincII, separated by agarose gel electrophoresis, blotted onto membrane and probed as described by Rouhiainen et al. (1995). According to the Southern blotting results, ten Nodularia strains representing toxic and non-toxic isolates from different regions of the Baltic Sea and isolates from Australia (Table 1) were purified to axenic by the softagarose-plating method (Rouhiainen et al., 1995).

RFLP of PCR-amplified 16S rRNA genes. 16S rRNA genes were amplified by PCR with primers fD1 and rD1 (Weisburg et al., 1991) as described by Lyra et al. (1997). The amplified genes were digested with AluI, DdeI, HaeIII, HhaI, MboI, $M s p \mathrm{I}$ and $R s a \mathrm{I}$. The restriction products were electrophoresed and recorded with a video camera (model WWBP500/G; Panasonic CCTV). The GELCOMPAR software (version 4, Applied Maths BVBA) and manual editing were used to verify that all bands were found and that no artifacts were included (Gerner-Smidt et al., 1998). The matrix of similarities was calculated on the basis of the Dice bandmatching coefficient (Dice, 1945) and the dendrogram was constructed by using the unweighted-pairs-group-methodwith-averages (UPGMA) clustering algorithm (Sneath \& Sokal, 1973).

16S rDNA sequence. 16S rRNA genes were amplified in two parts, with primers $\mathrm{pA} / \mathrm{pF}^{\prime}$ and $\mathrm{pD} / \mathrm{pH}^{\prime}$ (Edwards et al., 1989). The sequencing was done either by the solid-phase method (Hultman et al., 1991) and an automated ALF sequencer (Pharmacia) or by the DyeTerminator sequencing kit and the ABI PRISM 377XL DNA sequencer (Perkin Elmer). The sequences were assembled by the XGAP program of the Staden package (Bonfield et al., 1995) and aligned by the PILEUP program of the GCG package (Devereux et al., 1984). Phylogenetic trees were constructed by the neighbourjoining method and DNA parsimony method of PHYLIP (Felsenstein, 1993). In this program, bootstrap analysis was used to evaluate the tree topologies by performing 1000 resamplings.

Nucleotide sequence accession numbers. Strain designations and $16 \mathrm{~S}$ rRNA gene sequence accession numbers of cyanobacterial strains used in this study are as follows: Nodularia sp. BY1, AJ133177; Nodularia sp. GR8b, AJ133178; Nodularia sp. NSPI-05, AJ133179; Nodularia sp. NSOR-12, AJ133180; Nodularia sp. PCC 7804, AJ133181; Nodularia sp. UP16f, AJ133182; Nodularia sp. HKVV, AJ133183; Nodularia sp. PCC 73104/1, AJ133184; Aphanizomenon sp. 
Table 1. Nodularia strains used in this study

Culture collections: PCC, Institut Pasteur Culture Collection, Paris, France; NS, S. Blackburn, CSIRO, Division of Marine Research, Tasmania, Australia. The remaining strains are authors' isolates from the Baltic Sea. References: 1, Bolch et al. (1996); 2, Bolch et al. (1999); 3, Camm \& Stein (1974); 4, Castenholz (1989); 5, Fujii et al. (1997a); 6, Fujii et al. (1997b); 7, Giovannoni et al. (1988); 8, Herdman et al. (1979a); 9, Herdman et al. (1979b); 10, Komárek et al. (1993); 11, Kononen et al. (1993);

12, Lachance (1981); 13, Lehtimäki et al. (1994); 14, Lehtimäki et al. (1997); 15, Lyra et al. (1997); 16, Moisander et al. (1996);

17, Neilan (1996); 18, Neilan et al. (1995); 19, Neilan et al. (1997b); 20, Neilan et al. (1999); 21, Nelissen et al. (1994); 22, Nordin \& Stein (1980); 23, Rinne \& Tarkiainen (1978); 24, Rippka et al. (1979); 25, Sivonen et al. (1989a); 26, Sivonen et al. (1989b); 27, Šmarda et al. (1988); 28, Wilmotte (1994); 29, Wilmotte et al. (1994).

\begin{tabular}{|c|c|c|c|c|c|}
\hline Strain & Axenicity & $\begin{array}{l}\text { Nodularin } \\
\text { production }\end{array}$ & Geographical origin & $\begin{array}{l}\text { Date of } \\
\text { isolation }\end{array}$ & References \\
\hline HKVV & + & - & Brackish water, Baltic Sea & Not known & $2,6,13,15,16,20,23$ \\
\hline BY1 & + & + & Brackish water, Baltic Sea & $13 / 8 / 86$ & $1,2,13-16,20,25,26$ \\
\hline P38 (= EIB) & - & + & Brackish water, Baltic Sea. & $13 / 8 / 86$ & 25,26 \\
\hline GDR113 & - & + & Brackish water, Baltic Sea & $14 / 8 / 86$ & 25,26 \\
\hline F81 & + & + & Brackish water, Baltic Sea & $31 / 7 / 87$ & 25 \\
\hline TEILI & - & + & Brackish water, Baltic Sea & $4 / 8 / 87$ & 25 \\
\hline $59 / 22$ & - & + & Brackish water, Baltic Sea & $8 / 8 / 87$ & 25 \\
\hline AV1 & - & + & Brackish water, Baltic Sea & $8 / 8 / 87$ & 5,25 \\
\hline AV3 & + & + & Brackish water, Baltic Sea & $10 / 8 / 87$ & 25 \\
\hline AV33 & - & + & Brackish water, Baltic Sea & $10 / 8 / 87$ & 25 \\
\hline $55 / 15$ (=EIA) & - & + & Brackish water, Baltic Sea & $1 / 9 / 87$ & 25 \\
\hline HEM & + & + & Brackish water, Baltic Sea & $10 / 9 / 87$ & $13,15,20$ \\
\hline SR5b & - & + & Brackish water, Baltic Sea & $14 / 8 / 91$ & 11 \\
\hline GR8a & - & + & Brackish water, Baltic Sea & $3 / 8 / 92$ & - \\
\hline GR8b & + & + & Brackish water, Baltic Sea & $4 / 8 / 92$ & - \\
\hline TR183 & - & + & Brackish water, Baltic Sea & $18 / 7 / 93$ & - \\
\hline UP16a & + & - & Brackish water, Baltic Sea & $22 / 7 / 94$ & - \\
\hline UP16f & + & - & Brackish water, Baltic Sea & $22 / 7 / 94$ & - \\
\hline PCC 73104/1 & + & - & $\begin{array}{l}\text { Alkaline soil, Spotted Lake, BC, } \\
\text { Canada }\end{array}$ & 1972 & $\begin{array}{l}1-4,7-9,12,15,17-22, \\
24,28,29\end{array}$ \\
\hline PCC 7804 & + & + & Thermal spring, Dax, France & 1966 & $2,10,12,27$ \\
\hline NSPI-05 ( = PI9211-11) & + & + & $\begin{array}{l}\text { Coastal water, Peel Inlet, } \\
\text { Australia }\end{array}$ & $11 / 12 / 92$ & - \\
\hline NSOR-12 (= OR9301-08) & + & + & $\begin{array}{l}\text { Coastal water, Orielton Lagoon, } \\
\text { Tasmania, Australia }\end{array}$ & $1 / 10 / 93$ & 20 \\
\hline
\end{tabular}

TR183, AJ133155; Anabaena sp. CYA83/1, AJ133158; and Microcystis sp. PCC 7941, AJ133171. Three sequences were retrieved from GenBank: Nodularia sp. BCNOD9427, AJ22447; Nostoc sp. PCC 7120, X59559; and Oscillatoria agardhii CYA18, X84811.

Repetitive extragenic palindromic (REP)- and enterobacterial repetitive intergenic consensus (ERIC)-PCR. Central composite design (Montgomery, 1997) was used to optimize the temperature and the concentrations of $\mathrm{MgCl}_{2}$, nucleotides, enzyme, template and primers for REP- and ERIC-PCR amplification. Central composite design was provided by DATA ANALYSIS TOOLBOX (ProfMath Oy) of the MATLAB statistical software for Windows (The MathWorks). Conditions where the largest numbers of PCR products were amplified from the genome of Nodularia (PCC 73104/1) were chosen for REP- and ERIC-PCR analysis.

To examine the distribution of repetitive sequences in Nodularia strains, the primers pairs REP (1R-I, 2) and ERIC $(1 \mathrm{R}, 2)$ were used (Versalovic et al., 1991). Each $25 \mu 1$ reaction contained $50 \mathrm{ng}$ template DNA, 50 pmol primers,
$4 \mu \mathrm{g}$ BSA $\mu \mathrm{l}^{-1}$ and $2.8 \mathrm{U}$ Dynazyme DNA polymerase in Red Hot buffer $[750 \mathrm{mM}$ Tris/HCl (pH 9), $200 \mathrm{mM}$ $\left(\mathrm{NH}_{4}\right)_{2} \mathrm{SO}_{4}, 0 \cdot 1 \%$ Tween 20] with $10 \%$ (v/v) DMSO. Concentrations of $\mathrm{MgCl}_{2}$ and nucleotides were $3.3 \mathrm{mM}$ and $700 \mu \mathrm{M}$ (ERIC-PCR) or $6 \mathrm{mM}$ and $500 \mu \mathrm{M}$ (REP-PCR). PCR mixtures were overlaid with $25 \mu 1$ mineral oil. PCR amplification was performed with an initial denaturation at $95^{\circ} \mathrm{C}$ for $7 \mathrm{~min}$ followed by 30 cycles of denaturation at $94{ }^{\circ} \mathrm{C}$ for $1 \mathrm{~min}$, annealing at 39 or $47^{\circ} \mathrm{C}$ for 1 min with REP and ERIC primers, respectively, and extension at $65^{\circ} \mathrm{C}$ for $8 \mathrm{~min}$, with a single final extension at $65^{\circ} \mathrm{C}$ for $16 \mathrm{~min}$. PCR products were separated on $1 \%$ agarose gels containing ethidium bromide and the patterns were recorded with a video camera. The REP- and ERIC-PCR profiles were combined with the GeLCOMPAR software. The similarities between stored pairs of tracks were calculated by the Dice band-based coefficient and the groupings were visualized by the UPGMA clustering algorithm.

Automated ribotyping. DNA extracts were fingerprinted with the RiboPrinter microbial characterization system 
(Qualicon) as described by Bruce (1996) with the following modification: DNA, approximately $500 \mathrm{ng}$ per strain, was used for the analysis instead of cells. Digestions were sometimes partial, which was probably due to inhibitory substances present in the samples. The image files were analysed by the GELCOMPAR software. The Dice similarity coefficient was used and patterns were clustered by UPGMA (GELCOMPAR).

\section{RESULTS}

\section{Phenotypes of Nodularia}

By light-microscopic examination, no groups of strains could be recognized on the basis of cell size. The length and width of vegetative cells varied from $3 \cdot 1$ to $4 \cdot 7 \mu \mathrm{m}$ and from 4.6 to $8.3 \mu \mathrm{m}$, respectively (Table 2). Vegetative cells were shorter than they were wide (Table 2 , Fig. 1a-1), thus the length:width $(1: \mathrm{w})$ ratio of vegetative cells varied from 0.52 (strain NSPI-05) to 0.91 (strain F81). Heterocytes were $4 \cdot 2-7 \cdot 4 \mu \mathrm{m}$ long and 5.5-9.7 $\mu \mathrm{m}$ wide (Table 2 ). They were usually shorter than wide, but in some strains (F81, AV3, HEM), they were round (Table 2, Fig. 1c-e), meaning that the $1: \mathrm{w}$ ratio was $1 \cdot 0$. Furthermore, harsh culture conditions, e.g. starvation for phosphate used to germinate akinetes, increased the length of heterocytes until the cells were roundish. The lowest 1:w ratio $(0.52)$ was recorded for NSPI-05 strain. The length of cells never exceeded their width. The form of trichomes was variable (Fig. 1). According to nodularin and gas vesicle production, two groups of Nodularia could be recognized (Tables 1 and 2). Gas vesicles were not observed in non-toxic (HKVV, UP16a, UP16f and
PCC 73104/1) isolates or in some toxic isolates (HEM, BY1 and PCC 7804) (Table 2). However, strains HEM and BY1 had gas vesicles but lost them during storage in our laboratory.

Morphological analysis based on the criteria of Komárek et al. (1993) (see also Table 3) placed the non-toxic Nodularia strains as $N$. sphaerocarpa, while the toxic strains could be identified as $N$. spumigena or $N$. baltica. Based on the cell size, none of the strains belonged to $N$. litorea.

\section{Genetic diversity of non-axenic Nodularia strains}

To screen the genetic heterogeneity within non-axenic Nodularia isolates, the presence of STRR sequences was studied for 17 strains. Most Nodularia strains had very simple hybridization patterns compared with the pattern of Nostoc sp. strain PCC 7120 (Fig. 2). The toxic Baltic strains were different from the non-toxic strain HKVV. The toxic Australian strains were dissimilar to the Baltic isolates and to each other.

\section{Genetic characters of axenic Nodularia strains}

From the 12 axenic Nodularia strains (Table 1), three closely related RFLP genotypes were found on the basis of restriction fragment patterns of $16 \mathrm{~S}$ rRNA genes (Fig. 3). With this technique, the toxic Baltic strains were separated from the non-Baltic strains and from non-toxic Baltic strains. Of the seven restriction enzymes used, only two ( $D d e \mathrm{I}$ and $M s p \mathrm{I}$ ) yielded different profiles, while the others (AluI, HaeIII, HhaI,

Table 2. Morphological characters of the axenic Nodularia isolates used in this study

Cell dimensions given are means of 50 measurements. The numbers in parentheses are the SD and the minimum and maximum values. The presence or absence of gas vesicles is indicated.

\begin{tabular}{|c|c|c|c|c|c|}
\hline \multirow[t]{3}{*}{ Strain } & \multicolumn{4}{|c|}{ Size by light microscopy $(\mu \mathrm{m})$} & \multirow[t]{3}{*}{ Gas vesicles } \\
\hline & \multicolumn{2}{|c|}{ Vegetative cells } & \multicolumn{2}{|c|}{ Heterocysts } & \\
\hline & Length & Width & Length & Width & \\
\hline HEM & $3 \cdot 1(0 \cdot 68,2 \cdot 5,5 \cdot 0)$ & $4 \cdot 6(0 \cdot 64,3 \cdot 8,6 \cdot 3)$ & $6 \cdot 2(0 \cdot 39,5 \cdot 0,7 \cdot 5)$ & $6 \cdot 2(0 \cdot 39,5 \cdot 0,7 \cdot 5)$ & $-*$ \\
\hline BY1 & $4 \cdot 4(0 \cdot 63,3 \cdot 8,5 \cdot 0)$ & $5 \cdot 1(0 \cdot 30,5 \cdot 0,6 \cdot 3)$ & $5 \cdot 1(0 \cdot 38,5 \cdot 0,6 \cdot 3)$ & $6 \cdot 1(0 \cdot 38,5 \cdot 0,6 \cdot 3)$ & $-*$ \\
\hline AV3 & $4 \cdot 4(0 \cdot 68,3 \cdot 8,6 \cdot 3)$ & $5 \cdot 9(0 \cdot 90,5 \cdot 0,7 \cdot 5)$ & $7 \cdot 4(0 \cdot 34,6 \cdot 3,7 \cdot 5)$ & $7 \cdot 4(0 \cdot 34,6 \cdot 3,7 \cdot 5)$ & + \\
\hline GR $8 b$ & $4 \cdot 4(0 \cdot 63,3 \cdot 8,5 \cdot 0)$ & $6 \cdot 8(0 \cdot 62,6 \cdot 3,7 \cdot 5)$ & $5 \cdot 1(0 \cdot 49,3 \cdot 8,6 \cdot 3)$ & $7 \cdot 6(0 \cdot 30,7 \cdot 5,8 \cdot 8)$ & + \\
\hline F81 & $4 \cdot 5(0 \cdot 62,3 \cdot 8,5 \cdot 0)$ & $4 \cdot 9(0 \cdot 69,3 \cdot 8,6 \cdot 3)$ & $5 \cdot 5(0 \cdot 62,5 \cdot 0,6 \cdot 3)$ & $5 \cdot 5(0 \cdot 62,5 \cdot 0,6 \cdot 3)$ & + \\
\hline NSPI-05 & $4 \cdot 3(1 \cdot 2,2 \cdot 5,6 \cdot 3)$ & $8 \cdot 3(1 \cdot 1,7 \cdot 5,10 \cdot 0)$ & $5 \cdot 1(0 \cdot 30,5 \cdot 0,6 \cdot 3)$ & $9 \cdot 7(0 \cdot 55,8 \cdot 8,10 \cdot 0)$ & + \\
\hline NSOR-12 & $3 \cdot 3(1 \cdot 0,2 \cdot 5,5 \cdot 0)$ & $5 \cdot 1(0 \cdot 25,5 \cdot 0,6 \cdot 3)$ & $4 \cdot 8(0 \cdot 44,3 \cdot 8,5 \cdot 0)$ & $7 \cdot 2(0 \cdot 57,6 \cdot 3,7 \cdot 5)$ & + \\
\hline PCC 7804 & $3 \cdot 2(0 \cdot 63,2 \cdot 5,3 \cdot 8)$ & $5 \cdot 2(0 \cdot 49,5 \cdot 0,6 \cdot 3)$ & $4 \cdot 2(0 \cdot 59,3 \cdot 8,5 \cdot 0)$ & $6 \cdot 7(0 \cdot 61,6 \cdot 3,7 \cdot 5)$ & - \\
\hline HKVV & $4 \cdot 2(0 \cdot 60,3 \cdot 8,5 \cdot 0)$ & $7 \cdot 2(0 \cdot 69,6 \cdot 3,8 \cdot 8)$ & $5 \cdot 2(0 \cdot 49,5 \cdot 0,6 \cdot 3)$ & $7 \cdot 6(0 \cdot 38,7 \cdot 5,8 \cdot 8)$ & - \\
\hline UP16a & $4 \cdot 1(0 \cdot 58,3 \cdot 8,5 \cdot 0)$ & $5 \cdot 4(0 \cdot 60,5 \cdot 0,6 \cdot 3)$ & $5 \cdot 5(0 \cdot 61,5 \cdot 0,6 \cdot 3)$ & $7 \cdot 6(0 \cdot 25,7 \cdot 5,8 \cdot 8)$ & - \\
\hline UP16f & $4 \cdot 7(0 \cdot 79,3 \cdot 8,6 \cdot 3)$ & $6 \cdot 9(0 \cdot 72,5 \cdot 0,7 \cdot 5)$ & $4 \cdot 7(0 \cdot 79,3 \cdot 8,6 \cdot 3)$ & $7 \cdot 0(0 \cdot 63,6 \cdot 3,7 \cdot 5)$ & - \\
\hline PCC 73104/1 & $4 \cdot 3(0 \cdot 62,3 \cdot 8,5 \cdot 0)$ & $6 \cdot 6(0 \cdot 58,6 \cdot 3,7 \cdot 5)$ & $5 \cdot 0(0,5 \cdot 0,5 \cdot 0)$ & $7 \cdot 5(0,7 \cdot 5,7 \cdot 5)$ & - \\
\hline
\end{tabular}

* Gas vesicles have been observed previously. 

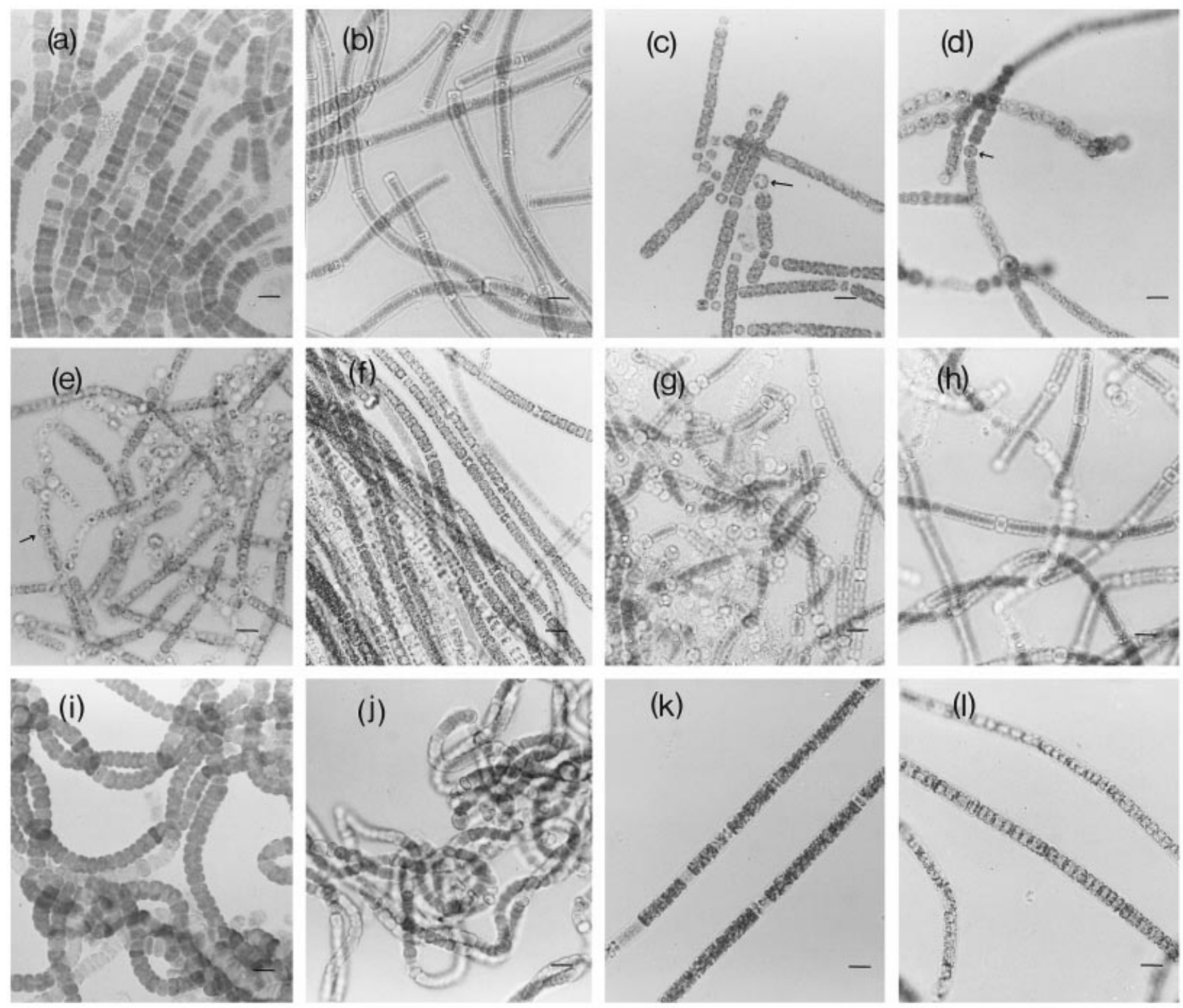

Fig. 1. Photomicrographs of Nodularia isolates: (a) HKVV, (b) BY1, (c) F81, (d) AV3, (e) HEM, (f) GR8b, (g) UP16a, (h) UP16f, (i) PCC 73104/1, (j) PCC 7804, (k) NSPI-05 and (I) NSOR-12. Bars, $10 \mu \mathrm{m}$. Some of the heterocytes are marked with arrows.

MboI and RsaI) produced similar patterns (data not shown) for the genus Nodularia. For cyanobacteria other than Nodularia, these five enzymes yielded different patterns.

The almost complete 16S rRNA gene sequences (1444-1445 bp) were determined for eight Nodularia strains, which were chosen on the basis of RFLP genotypes. A total of 1395 nucleotide sites were used to generate phylogenetic trees on the basis of the neighbour-joining method and the DNA parsimony method (Fig. 4). The topologies of these trees were highly similar. The minor differences between the two trees were for the nodes that were not supported by the bootstrap analysis (Fig. 4a, b). The internal branch lengths estimated by the distance method (Fig. 4a) were shorter than those estimated by the parsimony method (Fig. 4b).

The distance and parsimony methods gave two statistically supported clusters of Nodularia (Fig. 4), which were in agreement with the results from RFLP of PCR-amplified 16S rRNA genes (Fig. 3). One cluster comprised toxic strains and the other non-toxic strains (Fig. 4). However, the differences between strains in these two clusters were low, e.g. it was only $1.3 \%$ between PCC 7804 and the non-toxic strains. The most dissimilar toxic strains, BY1 and PCC 7804, were $99.0 \%$ similar in $16 \mathrm{~S}$ rRNA gene sequence, meaning that similarity within Nodularia strains originating 


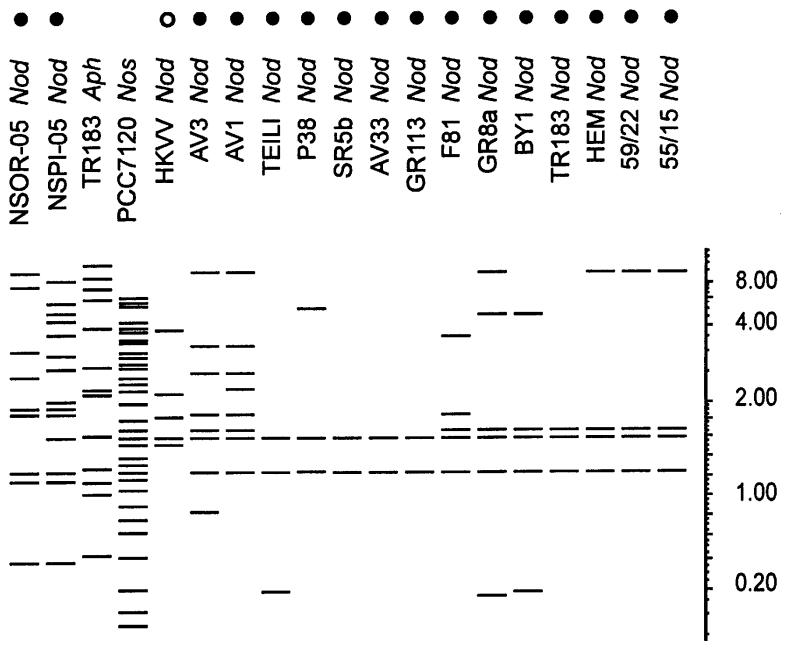

Fig. 2. Southern hybridization analysis of Hincll-digested total DNAs from several non-axenic Nodularia sp. strains (Nod), one Aphanizomenon sp. strain (Aph) and one Nostoc sp. strain (Nos). The size marker (kb) on the right was generated by digestion of lambda DNA with BstEll. Symbols: 0 , toxic; $\bigcirc$, non-toxic.

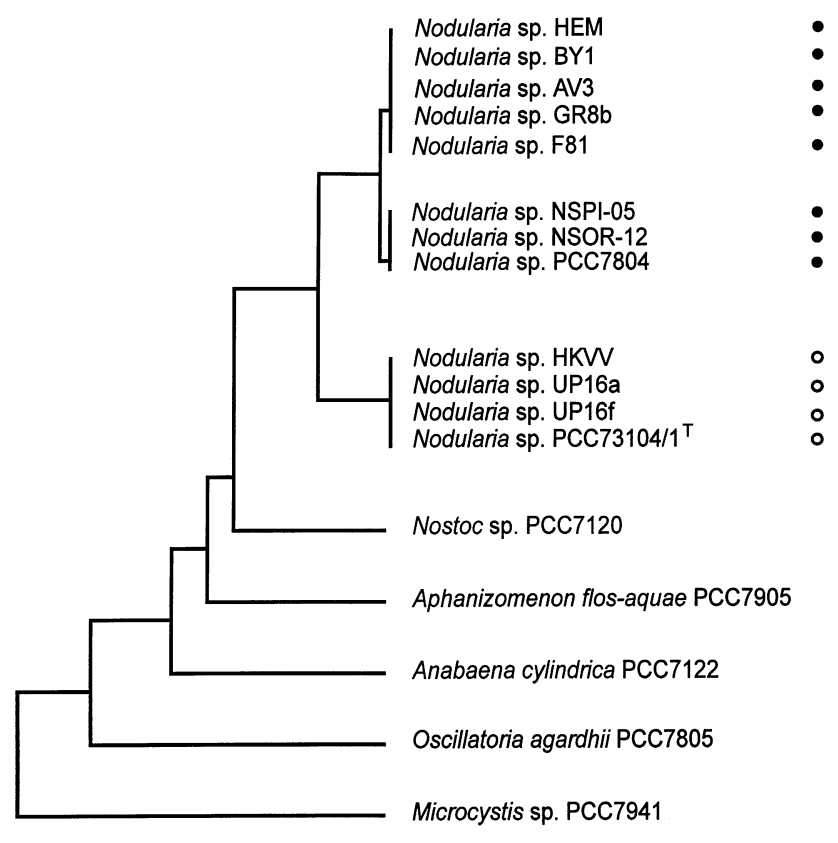

$\begin{array}{llllll}50 & 60 & 70 & 80 & 90 & 100\end{array}$ Similarity (\%)

Fig. 3. UPGMA dendrogram (GELCOMPAR) of RFLP analysis of $16 S$ rRNA genes of several Nodularia strains and other cyanobacterial genera. The restriction enzymes used were: Alul, Ddel, Haell, Hhal, Mbol, Mspl and Rsal. Symbols: 0 , toxic; $\bigcirc$, non-toxic; T, proposed type strain of $N$. spumigena.

from different regions (Table 1) was remarkably high. Grouping within the cluster containing the toxic strains was not supported statistically. Furthermore,
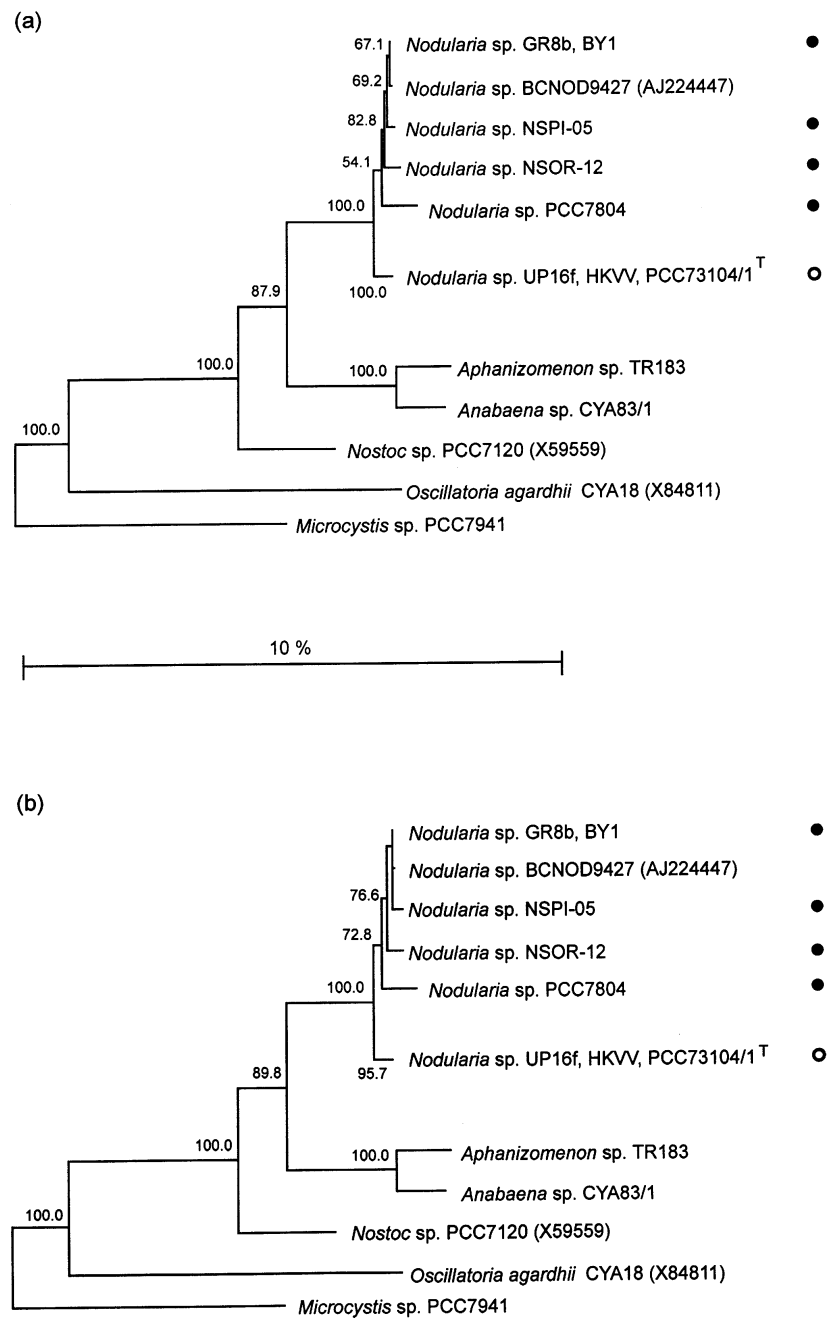

Fig. 4. Phylogenetic dendrograms based on cyanobacterial $16 \mathrm{~S}$ rRNA gene sequences and constructed by (a) the neighbourjoining method and (b) the parsimony method (PHYLIP). Scale bar represents $10 \%$ similarity of 1395 nucleotides. Percentages of 1000 bootstrap replicates are indicated near the nodes (only those values $>50 \%$ are shown). Sequences from GenBank are marked with accession numbers. Symbols: 0 , toxic; $\bigcirc$, nontoxic; T, proposed type strain of $N$. spumigena.

the 16S rDNA sequences of three non-toxic strains (PCC 73104/1, HKVV and UP16f) and of two toxic strains (BY1 and GR8b) were identical (Fig. 4).

REP- and ERIC-PCR patterns grouped the Nodularia strains in two groups (Fig. 5). The toxic strains formed one group. In this group, the strains from Australia and France were separated from the Baltic strains. With these techniques and the ribotyping analysis, the non-toxic strains (PCC 73104/1, HKVV and UP16f) were separated from the toxic strains (Figs 5 and 6). Strains PCC 73104/1 and HKVV were more similar than strain UP16f according to these techniques (Figs 5 and 6). In the RiboPrinter system, the DNA sample of strain PCC 7804 was only partially digested, even after an extra purification step with the Nucleon 


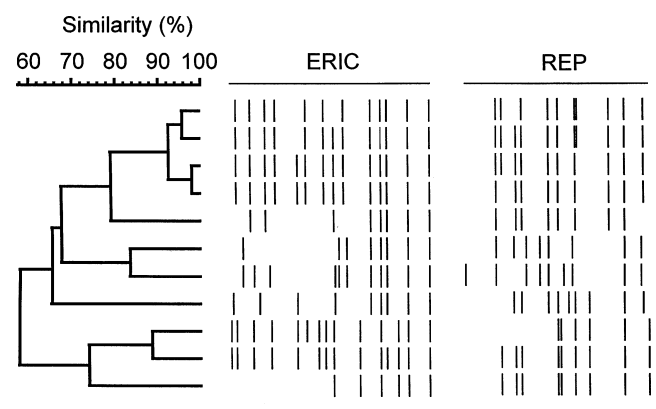

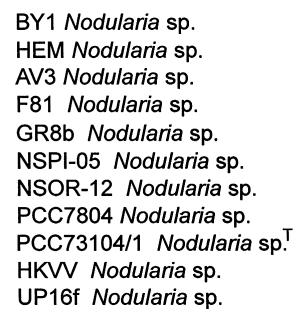

BY1 Nodularia sp. HEM Nodularia sp. AV3 Nodularia sp. F81 Nodularia sp. GR8b Nodularia sp. NSPI-05 Nodularia sp. NSOR-12 Nodularia sp. PCC7804 Nodularia sp. PCC73104/1 Nodularia sp.' HKVV Nodularia sp. UP16f Nodularia sp.

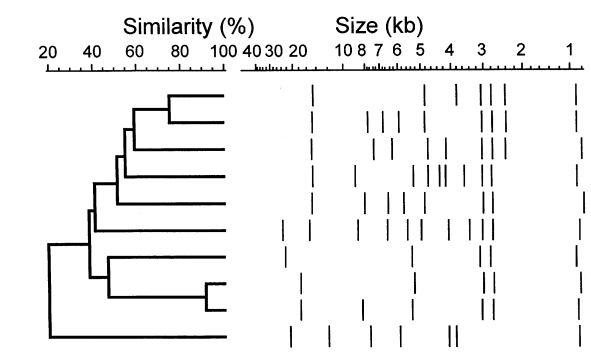

BY1 Nodularia sp. HEM Nodularia sp. AV3 Nodularia sp. GR8b Nodularia sp. F81 Nodularia sp. NSPI-05 Nodularia sp. UP16f Nodularia sp. PCC73104/1 Nodularia sp? HKVV Nodularia sp. PCC7120 Nostoc sp.

\begin{abstract}
Fig. 5. UPGMA dendrogram (GELCOMPAR) of repetitive sequences of Nodularia strains. The genomic fingerprints were generated by REP- and ERIC-PCR as indicated. The co-phenetic correlation value was $85.7 \%$. Symbols: O, toxic; $\bigcirc$, non-toxic; T, proposed type strain of $N$. spumigena.
\end{abstract}

PhytoPure system and, therefore, this sample was not included in the results.

\section{DISCUSSION}

Phenotypic characteristics such as the ability to form gas vesicles, which regulate the buoyancy of planktonic cyanobacteria, have been used to differentiate between the species of Nodularia (Šmarda et al., 1988; Komárek et al., 1993). In the laboratory, cyanobacterial isolates may lose their gas vesicles. Therefore, the ability to produce gas vesicles may not be a useful character to identify cultured strains, as confirmed in this study (see Table 2, BY1 and HEM strains). However, all of the toxic Nodularia strains examined were able to produce gas vesicles and it remains to be proven whether the non-toxic strains are unable to make these structures. Using cell size as a taxonomic criterion for cultured isolates of cyanobacteria also proved to be problematic, since this character may vary according to the growth conditions. The cell size of cultured Nodularia strains was not reflected in the 16S rRNA gene similarity. Morphological characterization of unicellular Merismopedia and Microcystis strains has also been unsuccessful in distinguishing genetic subclusters created by $16 \mathrm{~S}$ rDNA sequencing (Palinska et al., 1996; Otsuka et al., 1998). In this study, the phenotypic character of Nodularia strains that was consistent with the genotypic analysis was nodularin production. By all of the genotypic methods, the non-toxic Nodularia strains were differentiated from the toxic ones. Previously, using RAPD-PCR and $c p c B A$ IGS sequence data, Bolch et al. (1999) found genotypic distinctions between most toxic and non-toxic Nodularia isolates. Thus, nodularin production might be used as a marker in the taxonomy of Nodularia. In contrast to our study, no correlation between 16S rRNA gene evolution and toxicity of Microcystis strains was observed (Neilan et al., 1997a), although the Microcystis strains were clustered similarly by RFLP of ITS and toxin production (Neilan, 1996).

The occurrence of phylogenetic types of cyanobacteria and their distribution in marine ecosystems have been surveyed by sequencing 16S rRNA genes obtained from DNA isolated directly from the environment. The discovery of cyanobacterial clusters SAR6/SAR7 in both the Pacific and Atlantic Oceans (Giovannoni et al., 1990; Schmidt et al., 1991; Fuhrman et al., 1993; Mullins et al., 1995) revealed that this cyanobacterial cluster is distributed globally in the seas. Our study and the study of Bolch et al. (1999) of cyanobacterial sequences retrieved from laboratory cultures showed geographically diverse strains of Nodularia to be very close relatives. Similar findings were reported for Microcystis (Neilan et al., 1997a).

16S rRNA gene-based analysis and fingerprinting techniques revealed similar genotypic diversity for Nodularia strains. Previously, Vinuesa et al. (1998) had shown these techniques to be consistent when characterizing Bradyrhizobium strains.

Our results indicated that two closely related Nodularia genotypes are found in the Baltic Sea. One genotype consists only of non-toxic strains (UP16a, UP16f and HKVV). With 16S rRNA gene sequencing, these strains were identical to the proposed type strain of $N$. spumigena, PCC 73104/1 (Rippka et al., 1979; Nordin \& Stein, 1980), which is a soil isolate. All genetic markers separate it and other non-toxic strains from the toxic strains. The toxic strains form another genotype, which most closely fits the descriptions of $N$. 
Table 3. Morphological and ecological properties of planktonic and benthic Nodularia species

Data on morphological and ecological properties were taken from Komárek et al. (1993) and data on gas vesicles were derived from Šmarda \& Šmajs (1996). Phytoplankton includes microscopic aquatic organisms that float freely or have weak swimming abilities. The organisms found aggregated in the littoral zone are the metaphyton, which is synonymous with the term tychoplankton used previously. The euplankton refers to organisms living in the open waters. The term periphyton refers to microscopic organisms attached to objects projecting above the bottom sediment, whereas organisms living on or in it are benthic. NA, Not applicable.

\begin{tabular}{|c|c|c|c|c|c|}
\hline Character & N. baltica & N. harveyana & N. litorea & N. sphaerocarpa & N. spumigena \\
\hline \multicolumn{6}{|l|}{ Trichome: } \\
\hline Width $(\mu \mathrm{m})$ & $4 \cdot 8-6$ & $4-5$ & $10-15$ & $5-7$ & $6 \cdot 8-12$ \\
\hline Cell length $(\mu \mathrm{m})$ & $1 \cdot 8-4 \cdot 8$ & $1 \cdot 5-2 \cdot 5$ & $2-4$ & $3 \cdot 4-6$ & $2-4$ \\
\hline \multicolumn{6}{|l|}{ Heterocysts: } \\
\hline $\begin{array}{l}\text { Length } \times \text { width } \\
(\mu \mathrm{m})\end{array}$ & $2-5 \times 5-7 \cdot 5$ & $3-5 \times 4-6$ & $4 \cdot 4-6 \cdot 8 \times 10-15$ & $4-6 \times 5-7$ & $3 \cdot 5-5 \times 9-13 \cdot 7$ \\
\hline \multicolumn{6}{|l|}{ Akinetes: } \\
\hline $\begin{array}{l}\text { Length } \times \text { width } \\
(\mu \mathrm{m})\end{array}$ & $4-8 \times 5 \cdot 5-9$ & $4-8 \times 6-7$ & $6-10 \times 14-15$ & $7-12.7 \times 7-11.9$ & $6-10 \cdot 8 \times 10-12$ \\
\hline Observations & $\begin{array}{l}\text { Sometimes solitary } \\
\text { or in rows }\end{array}$ & $\begin{array}{l}\text { In series of two to } \\
\text { sixteen }\end{array}$ & $\begin{array}{l}\text { Solitary or in short } \\
\text { series }\end{array}$ & In series & $\begin{array}{l}\text { In series or } \\
\text { discontinuous } \\
\text { rows, rarely } \\
\text { solitary or in twos }\end{array}$ \\
\hline \multicolumn{6}{|l|}{ Gas vesicles: } \\
\hline Present? & Yes & No & Yes & No & Variable \\
\hline Density $\left(\mu \mathrm{m}^{-2}\right)$ & $140 / 160-180$ & NA & $215 / 230-240$ & NA & $139 / 160-180$ \\
\hline Ecology & $\begin{array}{l}\text { Metaphyton or } \\
\text { phytoplankton; } \\
\text { marine, brackish } \\
\text { and saline waters }\end{array}$ & $\begin{array}{l}\text { Benthic or } \\
\text { periphyton; saline } \\
\text { pools and lakes, } \\
\text { thermal springs } \\
\text { and marshes with } \\
\text { high salinity }\end{array}$ & $\begin{array}{l}\text { Phytoplankton; } \\
\text { marine, brackish } \\
\text { and saline waters }\end{array}$ & $\begin{array}{l}\text { Periphyton; } \\
\text { streams and } \\
\text { freshwater lakes. } \\
\text { Probably also } \\
\text { subaerophytic on } \\
\text { flooded alkaline } \\
\text { soils }\end{array}$ & $\begin{array}{l}\text { Metaphyton and } \\
\text { euplankton; } \\
\text { marine, brackish } \\
\text { and saline waters }\end{array}$ \\
\hline
\end{tabular}

baltica and $N$. spumigena (Table 3 ). According to the nomenclature of Komárek et al. (1993), the proposed type strain PCC 73104/1 is not typical of $N$. spumigena.

The phenotypic characters of the non-toxic Nodularia strains fit most closely to the description of $N$. sphaerocarpa, even without the recorded data of akinetes (Table 3). When akinetes were present, like in the HKVV strain, they occurred in series and were more or less spherical. The inability to produce gas vesicles is common in all typical strains of this species (Komárek et al., 1993). Although strains UP16a and UP16f have been isolated from the planktonic community, it is possible that these non-toxic strains without gas vesicles belong to benthic species. This suggestion is based on the small number (three) of nontoxic strains among approximately 100 toxic Nodularia strains we have isolated from the Baltic Sea. On the other hand, it might be that these non-toxic strains are rare in the planktonic community of the Baltic Sea. This is supported by the analysis of field samples; blooms samples containing Nodularia were frequently toxic (Sivonen et al., 1989b; Kononen et al., 1993). Strain HKVV has previously been classified as $N$. sphaerocarpa by using morphological criteria (Lehtimäki et al., 1994; Bolch et al., 1999). The morphological dimensions of this strain and some other strains were found to be variable in different studies (this study; Bolch et al., 1999). The difference in these features is probably due to the different growth conditions. Previously, different growth conditions such as $\mathrm{pH}$, temperature and salinity were reported to have no effect on dimensions of vegetative cells and heterocytes of Nodularia strains (Nordin \& Stein, 1980). In contrast, all of the morphological traits of unicellular halotolerant cyanobacteria were reported to be dependent on growth conditions, especially salinity (Garcia-Pichel et al., 1998).

On the basis of cell size, it was not possible to identify strain BY1 as N. baltica or N. spumigena in this study. Bolch et al. (1999) also failed to identify it to the species level. By $c p c B A$ sequence analysis, this strain has been placed with isolates BCNOD9401 and BCNOD9427 (Bolch et al., 1999), which were isolated from the Baltic Sea and which have previously been designated as $N$. litorea or $N$. spumigena according to trichome widths (Hayes \& Barker, 1997). By 16S 
rDNA sequence analysis, strain BY1 grouped with isolate BCNOD9427 (this study; Hayes \& Barker, 1997).

In this study, all of the toxic Nodularia strains, regardless of origin, belonged to the second genotype, which usually had the ability to form gas vesicles and which fits to the description of $N$. spumigena and N. baltica (Komárek et al., 1993). Even though the Nodularia isolates were closely related by $16 \mathrm{~S}$ rDNA sequence, the fingerprinting methods showed that there were differences among the isolates. However, the profiles of repetitive sequences, which have previously been shown to exist in cyanobacterial genomes (Versalovic et al., 1991; Rasmussen \& Svenning, 1998), indicated high genetic homogeneity among the toxic Baltic strains of Nodularia. The toxic strains NSPI-05 and NSOR-12 from Australia and PCC 7804 from France were found to be different from the Baltic Sea strains by all genotypic methods. Similarly, Bolch et al. $(1996,1999)$ have shown the Australian strains to be different from the Baltic strains. We also screened STRR sequences of non-axenic Nodularia strains with this method, which was applied previously to Anabaena in our laboratory (Rouhiainen et al., 1995). Although most of the Nodularia strains had only a few locations with STRR sequences, this method gave the same information as the other fingerprinting methods.

DNA-DNA homology studies have been used to measure the degree of relatedness between organisms with high 16S rRNA sequence similarity (Stackebrandt $\&$ Goebel, 1994). According to these authors, less than $70 \%$ DNA homology is expected for species having less than $97 \%$ sequence similarity. Here, Nodularia strains PCC 73104/1 and PCC 7804 had 98.7\% sequence similarity. According to the study of Lachance (1981), these strains had $65 \%$ relative binding. Therefore, these strains may be from the same genospecies, because the DNA relatedness of $65 \%$ is not much below the lower boundary level suggested by Wayne et al. (1987). Whether the Nodularia strains in the present study belong to one genospecies needs to be determined by DNA-DNA hybridization studies, since identity of 16S rRNA sequences does not guarantee species identity (Fox et al., 1992).

Nodularia strains that belong to the same genospecies may exhibit a cluster of morphotypes. Previously, Microcystis strains that share high sequence similarities of the 16S rDNA (Otsuka et al., 1998) and of the 16S-23S ITS (Otsuka et al., 1999) have been suspected to be members of the same genospecies showing various morphological expressions. Furthermore, similar results were found with the genus Merismopedia (Palinska et al., 1996).

Nodularia frequently form massive water-blooms in many brackish-water bodies. This genus can also produce hepatotoxin, which causes health hazards for animals and human beings. In this study, we have clarified the taxonomy of this genus by using different genotypic and phenotypic markers. We have shown a clear genotypic distinction between toxic and nontoxic Nodularia strains. Whether this separation is valid in natural Nodularia populations remains to be investigated.

\section{ACKNOWLEDGEMENTS}

We are grateful to Kaisa Kononen for providing cyanobacterial bloom samples from the Baltic Sea and to Susan Blackburn for providing non-axenic Nodularia isolates from Australia. We thank Kaisa Haukka, Maria Laamanen, Jarkko Rapala and Sari Repka for critical reading of the manuscript. Furthermore, we thank Irmgard Suominen and Irina Tsitko for help with the RiboPrinter and Seppo Kaijalainen for help with problems in molecular methods. This work was supported by the grants from the Academy of Finland, the Maj and Tor Nessling Foundation and the University of Helsinki.

\section{REFERENCES}

Albertano, P., Di Somma, D., Leonardi, D., Canini, A. \& Grilli Caiola, M. (1996). Cell structure of planktic cyanobacteria in the Baltic Sea. Algol Stud 83, 29-54.

Atlas, R. M. (1993). Tryptone glucose yeast agar. In Handbooks of Microbial Media, pp. 840. Edited by L. C. Parks. Boca Raton, FL: CRC Press.

Baker, P. D. \& Humpage, A. R. (1994). Toxicity associated with commonly occurring cyanobacteria in surface waters of the Murray-Darling Basin, Australia. Aust J Mar Freshwater Res 45, 773-786.

Barker, G. L. A., Hayes, P. K., O’Mahony, S. L., Vacharapiyasophon, P. \& Walsby, A. E. (1999). A molecular and phenotypic analysis of Nodularia (Cyanobacteria) from the Baltic Sea. $J$ Phycol 35, 931-937.

Bauer, C. C., Scappino, L. \& Haselkorn, R. (1993). Growth of the cyanobacterium Anabaena on molecular nitrogen: NifJ is required when iron is limited. Proc Natl Acad Sci USA 90, 8812-8816.

Bolch, C. J. S., Blackburn, S. I., Neilan, B. A. \& Grewe, P. M. (1996). Genetic characterization of strains of cyanobacteria using PCRRFLP of the $c p c B A$ intergenic spacer and flanking regions. $J$ Phycol 32, 445-451.

Bolch, C. J. S., Orr, P. T., Jones, G. J. \& Blackburn, S. I. (1999). Genetic, morphological and toxicological variation among globally distributed strains of Nodularia (Cyanobacteria). J Phycol 35, 339-355.

Bonfield, J. K., Smith, K. F. \& Staden, R. (1995). A new DNA sequence assembly program. Nucleic Acids Res 23, 4992-4999.

Bruce, J. (1996). Automated system rapidly identifies and characterizes microorganisms in food. Food Technol 50, 77-81.

Camm, E. L. \& Stein, J. R. (1974). Some aspects of the nitrogen metabolism of Nodularia spumigena (Cyanophyceae). Can J Bot 52, 719-726.

Castenholz, R. W. (1989). Subsection IV. Order Nostocales. In Bergey's Manual of Systematic Bacteriology, vol. 3, pp. 1780-1793. Edited by J. T. Staley, M. P. Bryant, N. Pfennig \& J. G. Holt. Baltimore, MD: Williams \& Wilkins.

Devereux, J., Haeberli, P. \& Smithies, O. (1984). A comprehensive set of sequence analysis programs for the VAX. Nucleic Acids Res 12, 387-395.

Dice, L. R. (1945). Measures of the amount of ecological association between species. $J$ Ecol 26, 297-302. 
Edwards, U., Rogall, T., Blöcker, H., Emde, M. \& Böttger, E. C. (1989). Isolation and direct complete nucleotide determination of entire genes. Characterization of a gene coding for $16 \mathrm{~S}$ ribosomal RNA. Nucleic Acids Res 17, 7843-7853.

Felsenstein, J. (1993). PHYLIP (Phylogeny Inference Package), version 3.5c. Department of Genetics, University of Washington, Seattle, WA, USA.

Fox, G. E., Wisotzkey, J. D. \& Jurtshuk, P., Jr (1992). How close is close: 16S rRNA sequence identity may not be sufficient to guarantee species identity. Int J Syst Bacteriol 42, 166-170.

Francis, G. (1878). Poisonous Australian lake. Nature 18, 11-12.

Fuhrman, J. A., McCallum, K. \& Davis, A. A. (1993). Phylogenetic diversity of subsurface marine microbial communities from the Atlantic and Pacific Oceans. Appl Environ Microbiol 59, 1294-1302.

Fujii, K., Sivonen, K., Adachi, K., Noguchi, K., Sano, H., Hirayama, K., Suzuki, M. \& Harada, K.-i. (1997a). Comparative study of toxic and non-toxic cyanobacterial products: novel peptides from toxic Nodularia spumigena AV1. Tetrahedron Lett 38, $5525-5528$.

Fujii, K., Sivonen, K., Adachi, K., Noguchi, K., Shimizu, Y., Sano, H., Hirayama, K., Suzuki, M. \& Harada, K.-i. (1997b). Comparative study of toxic and non-toxic cyanobacterial products: a novel glycoside, suomilide, from non-toxic Nodularia spumigena HKVV. Tetrahedron Lett 38, 5529-5532.

Garcia-Pichel, F., Nübel, U. \& Muyzer, G. (1998). The phylogeny of unicellular, extremely halotolerant cyanobacteria. Arch Microbiol 169, 469-482.

Gerner-Smidt, P., Graves, L. M., Hunter, S. \& Swaminathan, B. (1998). Computerized analysis of restriction fragment length polymorphism patterns: comparative evaluation of two commercial software packages. J Clin Microbiol 36, 1318-1323.

Giovannoni, S. J., Turner, S., Olsen, G. J., Barns, S., Lane, D. J. \& Pace, N. R. (1988). Evolutionary relationships among cyanobacteria and green chloroplasts. J Bacteriol 170, 3584-3592.

Giovannoni, S. J., Britschgi, T. B., Moyer, C. L. \& Field, K. G. (1990). Genetic diversity in Sargasso Sea bacterioplankton. Nature 345, 60-63.

Golden, J. W., Carrasco, C. D., Mulligan, M. E., Schneider, G. J. \& Haselkorn, R. (1988). Deletion of a 55-kilobase-pair DNA element from the chromosome during heterocyst differentiation of Anabaena sp. strain PCC 7120. J Bacteriol 170, 5034-5041.

Hayes, P. K. \& Barker, G. L. A. (1997). Genetic diversity within Baltic Sea populations of Nodularia (Cyanobacteria). J Phycol 33, 919-923

Herdman, M., Janvier, M., Waterbury, J. B., Rippka, R., Stanier, R. Y. \& Mandel, M. (1979a). Deoxyribonucleic acid base composition of cyanobacteria. J Gen Microbiol 111, 63-71.

Herdman, M., Janvier, M., Rippka, R. \& Stanier, R. Y. (1979b). Genome size of cyanobacteria. J Gen Microbiol 111, 73-85.

Hultman, T., Bergh, S., Moks, T. \& Uhlen, M. (1991). Bidirectional solid-phase sequencing of in vitro-amplified plasmid DNA. BioTechniques 10, 84-93.

Jones, G. J., Blackburn, S. I. \& Parker, N. S. (1994). A toxic bloom of Nodularia spumigena Mertens in Orielton Lagoon, Tasmania. Aust J Mar Freshwater Res 45, 787-800.

Komárek, J., Hübel, M., Hübel, H. \& Šmarda, J. (1993). The Nodularia studies. 2. Taxonomy. Algol Stud 68, 1-25.

Kononen, K., Sivonen, K. \& Lehtimäki, J. (1993). Toxicity of phytoplankton blooms in the Gulf of Finland and Gulf of Bothnia, Baltic Sea. In Toxic Phytoplankton Blooms in the Sea, pp. 269-273. Edited by T. J. Smayda \& Y. Shimizu. Amsterdam: Elsevier.

Kotai, J. (1972). Instructions for Preparation of Modified Nutrient Solution Z8 for Algae, publication B-11/69. Blindern, Oslo: Norwegian Institute for Water Research.

Lachance, M.-A. (1981). Genetic relatedness of heterocystous cyanobacteria by deoxyribonucleic acid-deoxyribonucleic acid reassociation. Int J Syst Bacteriol 31, 139-147.

Lehtimäki, J., Sivonen, K., Luukkainen, R. \& Niemelä, S. I. (1994). The effects of incubation time, temperature, light, salinity, and phosphorus on growth and hepatotoxin production by Nodularia strains. Arch Hydrobiol 130, 269-282.

Lehtimäki, J., Moisander, P., Sivonen, K. \& Kononen, K. (1997). Growth, nitrogen fixation, and nodularin production by two Baltic Sea cyanobacteria. Appl Environ Microbiol 63, 1647-1656.

Lyra, C., Hantula, J., Vainio, E., Rapala, J., Rouhiainen, L. \& Sivonen, K. (1997). Characterization of cyanobacteria by SDSPAGE of whole-cell proteins and PCR/RFLP of the 16S rRNA gene. Arch Microbiol 168, 176-184.

Moisander, P., Lehtimäki, J., Sivonen, K. \& Kononen, K (1996). Comparison of ${ }^{15} \mathrm{~N}_{2}$ and acetylene reduction methods for the measurement of nitrogen fixation by Baltic Sea cyanobacteria. Phycologia 35, 140-146.

Montgomery, D. C. (1997). Design and Analysis of Experiments, 4th edn. New York: John Wiley.

Mullins, T. D., Britschgi, T. B., Krest, R. L. \& Giovannoni, S. J. (1995). Genetic comparisons reveal the same unknown bacterial lineages in Atlantic and Pacific bacterioplankton communities. Limnol Oceanogr 40, 148-158.

Nehring, S. (1993). Mortality of dogs associated with a mass development of Nodularia spumigena (Cyanophyceae) in a brackish lake at the German North Sea coast. J Plankton Res 15, 867-872.

Neilan, B. A. (1996). Detection and identification of cyanobacteria associated with toxic blooms: DNA amplification protocols. Phycologia 35, 147-155.

Neilan, B. A., Jacobs, D. \& Goodman, A. E. (1995). Genetic diversity and phylogeny of toxic cyanobacteria determined by DNA polymorphisms within the phycocyanin locus. Appl Environ Microbiol 61, 3875-3883.

Neilan, B. A., Jacobs, D., del Dot, T., Blackall, L. L., Hawkins, P. R., Cox, P. T. \& Goodman, A. E. (1997a). rRNA sequences and evolutionary relationships among toxic and nontoxic cyanobacteria of the genus Microcystis. Int J Syst Bacteriol 47, 693-697.

Neilan, B. A., Stuart, J. L., Goodman, A. E., Cox, P. T. \& Hawkins, P. R. (1997b). Specific amplification and restriction polymorphisms of the cyanobacterial rRNA operon spacer region. Syst Appl Microbiol 20, 612-621.

Neilan, B. A., Dittmann, E., Rouhiainen, L., Bass, R. A., Schaub, V., Sivonen, K. \& Börner, T. (1999). Nonribosomal peptide synthesis and the toxigenicity of cyanobacteria. J Bacteriol 181, 4089-4097.

Nelissen, B., Wilmotte, A., Neefs, J.-M. \& De Wachter, R. (1994). Phylogenetic relationships among filamentous helical cyanobacteria investigated on the basis of 16S rRNA gene sequence analysis. Syst Appl Microbiol 17, 206-210.

Nordin, R. N. \& Stein, J. R. (1980). Taxonomic revision of Nodularia (Cyanophyceae/Cyanobacteria). Can $J$ Bot 58, 1212-1224

Ohta, T., Sueoka, E., lida, N. and 7 other authors (1994). 
Nodularin, a potent inhibitor of protein phosphatases 1 and $2 \mathrm{~A}$, is a new environmental carcinogen in male F344 rat liver. Cancer Res 54, 6402-6406.

Otsuka, S., Suda, S., Li, R., Watanabe, M., Oyaizu, H., Matsumoto, S. \& Watanabe, M. M. (1998). 16S rDNA sequences and phylogenetic analyses of Microcystis strains with and without phycoerythrin. FEMS Microbiol Lett 164, 119-124.

Otsuka, S., Suda, S., Li, R., Watanabe, M., Oyaizu, H., Matsumoto, S. \& Watanabe, M. M. (1999). Phylogenetic relationships between toxic and non-toxic strains of the genus Microcystis based on $16 \mathrm{~S}$ to $23 \mathrm{~S}$ internal transcribed spacer sequence. FEMS Microbiol Lett 172, 15-21.

Palinska, K. A., Liesack, W., Rhiel, E. \& Krumbein, W. E. (1996). Phenotype variability of identical genotypes: the need for a combined approach in cyanobacterial taxonomy demonstrated on Merismopedia-like isolates. Arch Microbiol 166, 224-233.

Rasmussen, U. \& Svenning, M. M. (1998). Fingerprinting of cyanobacteria based on PCR with primers derived from short and long tandemly repeated repetitive sequences. Appl Environ Microbiol 64, 265-272.

Rinehart, K. L., Harada, K.-I., Namikoshi, M. and 8 other authors (1988). Nodularin, microcystin, and the configuration of Adda. $J$ Am Chem Soc 110, 8557-8558.

Rinne, I. \& Tarkiainen, E. (1978). Algal tests used to study the chemical factors regulating the growth of planktonic algae in the Helsinki sea area. Mitt Int Ver Limnol 21, 527-546.

Rippka, R. \& Herdman, M. (1992). Pasteur Culture Collection of Cyanobacterial Strains in Axenic Culture. Catalogue $\mathcal{E}$ Taxonomic Handbook, vol. 1, Catalogue of Strains, 1992/1993. Paris: Institut Pasteur.

Rippka, R., Deruelles, J., Waterbury, J. B., Herdman, M. \& Stanier, R. Y. (1979). Generic assignments, strain histories and properties of pure cultures of cyanobacteria. J Gen Microbiol 111, 1-61.

Rouhiainen, L., Sivonen, K., Buikema, W. J. \& Haselkorn, R. (1995). Characterization of toxin-producing cyanobacteria by using an oligonucleotide probe containing a tandemly repeated heptamer. J Bacteriol 177, 6021-6026.

Schmidt, T. M., DeLong, E. F. \& Pace, N. R. (1991). Analysis of a marine picoplankton community by $16 \mathrm{~S}$ rRNA gene cloning and sequencing. J Bacteriol 173, 4371-4378.

Sivonen, K., Kononen, K., Carmichael, W. W., Dahlem, A. M., Rinehart, K. L., Kiviranta, J. \& Niemelä, S. I. (1989a). Occurrence of the hepatotoxic cyanobacterium Nodularia spumigena in the Baltic Sea and structure of the toxin. Appl Environ Microbiol 55, 1990-1995.
Sivonen, K., Kononen, K., Esala, A.-L. \& Niemelä, S. I. (1989b). Toxicity and isolation of the cyanobacterium Nodularia spumigena from the southern Baltic Sea in 1986. Hydrobiologia 185, 3-8.

Skulberg, O. M. (1990). Culture Collection of Algae. Catalogue of Strains. Oslo: Norwegian Institute for Water Research.

Šmarda, J. \& Šmajs, D. (1996). Morphological types of gas vesicles. Algol Stud 83, 485-499.

Šmarda, J., Komárek, J., Cáslavská, J. \& Hübel, M. (1988). The Nodularia studies. 1. Introduction, fine structure. Arch Hydrobiol Suppl 80, 109-129.

Sneath, P. H. A. \& Sokal, R. R. (1973). Numerical Taxonomy. San Francisco: W. H. Freeman.

Stackebrandt, E. \& Goebel, B. M. (1994). Taxonomic note: a place for DNA-DNA reassociation and 16S rRNA sequence analysis in the present species definition in bacteriology. Int $J$ Syst Bacteriol 44, 846-849.

Versalovic, J., Koeuth, T. \& Lupski, J. R. (1991). Distribution of repetitive DNA sequences in eubacteria and application to fingerprinting of bacterial genomes. Nucleic Acids Res 19, 6823-6831.

Vinuesa, P., Rademaker, J. L. W., de Bruijn, F. J. \& Werner, D. (1998). Genotypic characterization of Bradyrhizobium strains nodulating endemic woody legumes of the Canary Islands by PCR-restriction fragment length polymorphism analysis of genes encoding 16S rRNA (16S rDNA) and 16S-23S rDNA intergenic spacers, repetitive extragenic palindromic PCR genomic fingerprinting, and partial $16 \mathrm{~S}$ rDNA sequencing. Appl Environ Microbiol 64, 2096-2104.

Walsby, A. E., Hayes, P. K. \& Boje, R. (1995). The gas vesicles, buoyancy and vertical distribution of cyanobacteria in the Baltic Sea. Eur J Phycol 30, 87-94.

Wayne, L. G., Brenner, D. J., Colwell, R. R. and 9 other authors (1987). Report of the ad hoc committee on reconciliation of approaches to bacterial systematics. Int J Syst Bacteriol 37, 463-464.

Weisburg, W. G., Barns, S. M., Pelletier, D. A. \& Lane, D. J. (1991). $16 \mathrm{~S}$ ribosomal DNA amplification for phylogenetic study. $J$ Bacteriol 173, 697-703.

Wilmotte, A. (1994). Molecular evolution and taxonomy of the cyanobacteria. In The Molecular Biology of Cyanobacteria, pp. 1-25. Edited by D. A. Bryant. Dordrecht: Kluwer.

Wilmotte, A., Neefs, J.-M. \& De Wachter, R. (1994). Evolutionary affiliation of the marine nitrogen-fixing cyanobacterium Trichodesmium sp. strain NIBB 1067 , derived by 16 S ribosomal RNA sequence analysis. Microbiology 140, 2159-2164. 